\title{
SEKSUALITAS DALAM LONTAR TINGKAHING SARASMI IMPLIKASI TERHADAP MASYARAKAT DI KECAMATAN DENPASAR TIMUR
}

\author{
Oleh Ni Luh Gede Astiti Dewi
}

\begin{abstract}
ABSTRAK
Lontar Tingkahing Sarasmi menjelaskan tentang hubungan seksual pada saat pernikahan yang di dalamnya menjelaskan etika seksualitas ketika melakukan hubungan seksual sehingga mereka dapat mencapai puncak kenikmatan seksual dan etika mendapatkan anak yang diinginkan. Jadi mengetahui hal ini dapat membantu masyarakat untuk mengatasi masalah dalam rumah tangga dan mendapatkan anak yang mereka inginkan. Maka nantinya anak-anak yang dilahirkan akan menjadi generasi yang memiliki kualitas yang baik dan dapat memiliki dampak yang baik terhadap lingkungan.

Dalam Lontar Tingkahing Sarasmai memiliki konsep seksualitas yang mencakup konsep agama dan konsep penggunaan seksualitas. Dalam konsep seksualitas, ini menjelaskan cinta para dewa dalam tubuh manusia sehingga hubungan seksual dikatakan sakral dan ada larangan melakukan hubungan seksual karena dapat mempengaruhi karakter anak. Selain itu, ada etika seksualitas, yaitu: etika berhubungan seks dengan istri, etika memegang istri, etika menginginkan putra dan putri, etika menginginkan putra yang kuat, etika menginginkan putra dan putri yang utama, etika menginginkan anak yang cantik, dan etika menginginkan putra yang berumur panjang. Serta bagaimana implikasi seksualitas di Lontar Tingkahing Sarasmi pada masyarakat di Kecamatan Denpasar Timur, termasuk implikasi gaya hidup, implikasi terhadap perilaku sosial masyarakat, implikasi bagi orang yang menerapkan etika seksualitas di Lontar Tingkahing Sarasmi, dan implikasi bagi orang yang tidak menerapkan etika seksualitas di Lontar Tingkahing Sarasmi.
\end{abstract}

Kata kunci: Implikasi, Seksualitas dan Lontar Tingkahing Sarasmi

\section{ABSTRACT}

Lontar Tingkahing Sarasmi explained about sexual relations at the time of marriage which in it explained sexuality ethics when having sexual relations so that they could reach the peak of sexual pleasure and the ethics of getting the desired son. So knowing this can help the community to deal with problems in the household and get the children they want. Then later children who are born will be a generation that has good quality and can have a good impact on the environment.

In Lontar Tingkahing Sarasmai has the concept of sexuality which includes religious concepts and concepts of the use of sexuality. In the concept of sexuality, this explains the love of the gods in the human body so that sexual relations are said to be sacred and there is a prohibition on sexual intercourse because it can affect the character of the child. In addition, there are sexuality ethics, namely: ethics of having sex with wives, ethics of wife holding, ethics of wanting sons and daughters, ethics of wanting powerful sons, ethics of wanting sons and daughters of the main, ethics of wanting beautiful children, and ethics of wanting long-lived sons. As well as how the implications of sexuality in Lontar Tingkahing Sarasmi on the people in East Denpasar Subdistrict, including lifestyle implications, implications for community social behavior, implications for people who apply sexuality ethics in Lontar Tingkahing Sarasmi, and implications for people who do not apply sexuality ethics in Lontar Tingkahing Sarasmi.

Keywords: Implications, Sexuality and Lontar Tingkahing Sarasmi 


\begin{abstract}
ABSTRAK
Lontar Tingkahing Sarasmi menjelaskan mengenai hubungan seksual ketika masa berumah tangga yang didalamnya menjelaskan etika seksualitas ketika melakukan hubungan seksual sehingga dapat mencapai puncak kenikmatan seksual dan etika memperoleh putra yang diinginkan. Sehingga dengan mengetahui hal tersebut dapat membantu masyarakat dalam menghadapi masalah dalam rumah tangga serta memperoleh anak-anak yang diinginkan. Maka nantinya anak-anak yang terlahir akan menjadi generasi yang mempunyai kualitas yang bagus serta dapat ikut memberi dampak yang baik pada lingkungan.

Pada Lontar Tingkahing Sarasmai terdapapat konsep seksualitas yang mencakup konsep religius dan konsep penggunaan seksualitas. Dalam konsep seksualitas, ini menjelaskan persemayaman para dewa di bagian tubuh manusia sehingga hubungan seksual dikatakan sakral dan terdapat larangan dalam berhubungan seksual karena dapat mempengaruhi karakter anak. Selain itu, terdapat etika seksualitas yaitu: etika bersenggama dengan istri, etika memangku istri, etika menginginkan putra suputra, etika menginginkan putra sakti, etika menginginkan putra sidha utama, etika menginginkan putra rupawan, dan etika menginginkan putra panjang umur. Serta bagaimana implikasi seksualitas dalam Lontar Tingkahing Sarasmi terhadap masyarakat di Kecamatan Denpasar Timur, termasuk implikasi terhadap gaya hidup, implikasi terhadap perilaku sosial masyarakat, implikasi bagi masyarakat yang menerapkan etika seksualitas dalam Lontar Tingkahing Sarasmi, dan implikasi bagi masyarakat yang tidak menerapkan etika seksualitas dalam Lontar Tingkahing Sarasmi.
\end{abstract}

\title{
Kata Kunci: Implikasi, Seksualitas, dan Lontar Tingkahing Sarasmi.
}

\section{PENDAHULUAN}

Kesusastraan Bali merupakan hasil karya cipta sastrawan serta merupakan hasil imajinasi orang Bali yang menjadi kebudayaan dan dilestarikan secara turun temurun, yang lazimnya menggunakan bahasa Bali sebagai media komunikasinya serta memuat tentang kehidupan sosial masyarakat Bali secara imajinatif. Karyakarya sastra yang bernilai luhur itu tetap hidup dan berkembang sampai sekarang. Hal ini terbukti dengan adanya peninggalan- peninggalan karya sastra yang sebagian besar ditulis di atas daun rontal dengan menggunakan huruf Bali.

Karya-karya sastra yang bernilai luhur itu tetap hidup dan berkembang sampai sekarang. Hal ini terbukti dengan adanya peninggalanpeninggalan karya sastra yang sebagian besar ditulis di atas daun rontal dengan menggunakan huruf Bali. Karya sastra tradisional yang ditulis di atas daun rontal, bila dilihat dari jenisnya ada yang berbentuk prosa dan berbentuk puisi. Karya sastra tradisional yang berbentuk prosa, yakni seperti parwa, babad, tutur, wariga, kanda, dan susila. Sedangkan karya sastra tradisional berbentuk puisi dapat diklasifikasikan dalam bentuk tembang, yakni seperti kekawin, kidung, dan geguritan. Karya sastra pula dapat mencerminkan pola kehidup masyarakat.

Menurut Sukayasa (2010: 105) sastra Bali merupakan refleksi budaya Bali. Bila dipersonifikasikan, kebudayaan Bali dan sastranya ternyata adalah ayah dan ibu bagi masyarakat Bali. Keduanya adalah kekayaan yang maha penting karena menjadi pedoman dan sumber kehidupan. Lontar merupakan salah satu bentuk tertulis kebudayaan masa lampau yang disimpan dan dipelihara oleh generasi yang mewarisi.

Seiring dengan perkembangan zaman generasi muda mulai acuh dengan karya sastra para seniman terdahulu. Generasi muda menganggap bahwa karyasastratersebutsudahkuno dankurangmenarik untuk dipelajari. Lontar Tingkahing Sarasmi 
sebagai salah satu karya peninggalan kebudayaan yang membahas mengenai seksualitas khususnya ajaran bersenggama pada masa berumah tangga. Lontar ini bertuliskan huruf Bali atau aksara Bali dengan menggunakan bahasa bahasa Jawa Kuno atau bahasa Kawi. Seksualitas merupakan suatu ekspresi hasrat erotik atau birahi manusia yang dikonstruksikan dan diwariskan dari satu generasi ke generasi berikut dengan melibatkan faktor politik, ekonomi, nilai budaya, dan ajaran agama. Sebab, seksualitas merupakan esensi kemanusiaan paling nyata karena menunjukkan jati diri manusia yang paling dalam.

Lontar Tingkahing Sarasmi menjelaskan mengenai hubungan seksual ketika masa berumah tangga atau grahasta asrama yang didalamnya menjelaskan etika seksualitas ketika melakukan hubungan seksual sehingga dapat mencapai puncak kenikmatan seksual dan etika memperoleh putra yang diinginkan. Sehingga dengan mengetahui hal tersebut dapat membantu masyarakat dalam menghadapi masalah dalam rumah tangga serta memperoleh anak-anak yang diinginkan. Maka nantinya anak-anak yang terlahir akan menjadi generasi yang mempunyai bibit, bebet dan bobot yang bagus serta dapat ikut dalam memberi dampak yang baik.

Dengan demikian pengetahuan atau ajaran seksualitas sangat perlu diketahui sejak dini. Sehingga sedikitnya pengetahuan tentang seks atau persepsi yang buruk tentang seks akan membawa seseorang menggunakan seks dengan cara yang buruk, sebaliknya pengetahuan yang benar dan relevan tentang seks akan menghasilkan tanggung jawab sosial.

\section{PEMBAHASAN}

Kamus Besar Bahasa Indonesia (Tim Penyusun, 2008: 767-768) mengatakan "seks adalah jenis kelamin, sedangkan seksual berkenaan dengan seks, berkenaan dengan perkara persetubuhan antara laki- laki dan perempuan". Istilah "seks" secara etimologis, berasal dari bahasa Latin "sexus" kemudian diturunkan menjadi bahasa Perancis Kuno "sexe". Seksualitas adalah seks dalam arti yang luas, yaitu segala hal yang terjadi sebagai akibat (konsekwensi) dari adanya perbedaan jenis kelamin, antara lain pembedaan tingkah laku (kasar, genit, lembut dan lain-lain), perbedaan atribut (pakaian dan nama), perbedaan peran dan pekerjaan, hubungan antara pria dan wanita (tata krama pergaulan, percintaan, pacaran, perkawinan dan lain-lain).

Suarka (2012: 88) menyebutkan bahwa Lontar merupakan sebuah naskah yang memuat teks tentang ajaran tertentu sesuai dengan nama dari lontar tersebut. Tingkahing Sarasmi jika dilihat dari kata yang membangunnya maka terdiri dari dua kata, yaitu Tingkahing dan Sarasmi. Kata Tingkahing berarti perilaku dan kata Sarasmi berarti asmara atau bersenggama. Jadi Tingkahing Sarasmi berarti perilaku ketika hendak bersenggama atau berhubungan badan. Dalam lontar ini membahas mengenai etika seksualitas pada hubungan suami istri ketika masa berumah tangga dan mantra- mantra yang digunakan ketika bersenggama agar dapat mempunyai anak yang diinginkan oleh pasangan suami istri.

Implikasi dalam kamus besar Bahasa Indonesia diartikan sebagai keterlibatan atau keadaan terlibat manusia sebagai obyek percobaan atau penelitian yang semakin terasa manfaat dan kepentingannya. Implikasi juga dapat diartikan sebagai suatu akibat yang terjadi karena suatu hal. Pengertian implikasi yang dimaksud dalam penelitian ini adalah keterlibatan dan akibat yang terjadi setelah melaksanakan atau tidak melaksanakan etika seksualitas menurut Lontar Tingkahing Sarasmi terhadap masyarakat Di Kecamatan Denpasar Timur.

\section{II.1 Konsep Seksualitas Dalam Lontar Tingkahing Sarasmi}

Pada zaman yang semakin berkembang ini, seksualitas menjadi hal yang menarik diperbincangkan. Hal tersebut dikarenakan 
banyak terjadi penyimpangan perilaku akibat seksualitas. Hubungan seksual (atau koitus atau sanggama) pada dasarnya adalah penyisipan dan dorongan penis, biasanya ketika ereksi ke dalam vagina untuk kenikmatan seksual, reproduksi, atau keduanya. Hal ini juga dikenal sebagai hubungan seks vaginal atau seks vaginal. Bentuk lain dari hubungan seksual penetratif termasuk seks anal (penetrasi anus oleh penis), seks oral (penetrasi mulut oleh penis atau penetrasi oral alat kelamin wanita), fingering (penetrasi seksual oleh jari), dan penetrasi dengan menggunakan dildo (terutama dildo tali pengikat). Kegiatan ini melibatkan keintiman fisik antara dua atau lebih individu dan biasanya digunakan di antara manusia sematamata untuk kesenangan fisik atau emosional dan dapat berkontribusi pada ikatan manusia. Ikatan manusia disini dimaksudkan hubungan seksual yang dilaksanakan atau dilakukan oleh pasangan suami istri, seperti halnya yang terdapat pada Lontar Tingkahing Sarasmi.

Hubungan seksual yang dilaksanakan oleh pasangan suami istri adalah salah satu cara untuk memuja Ida Sang Hyang Widhi Wasa dengan yoga. Pada saat melakukan hubungan seksual, seorang suami tidak boleh memiliki pikiran yang buruk serta pakaian yang digunakan harus yang bagus dan bersih karena tidak diperbolehkan menggunakan pakaian yang kucel, kotor, robek, dan lainnya yang tidak bagus dilihat oleh sang istri.

Menurut Djaya dan Asmara (2004: 214) mengatakan "yang termasuk sarana penggugah hasrat ini adalah segala sesuatu yang digunakan untuk semakin menambah gairah keduanya sebelum berolah asmara, semisal pakaian atau busana. Pakaian dikatakan pantas untuk dikenakan jika sesuai dengan tempat dan peristiwa dimana pemakainya berada". Seperti yang dijelaskan, maka sarana yang digunakan agar mempunyai keinginan untuk berhubungan seksual adalah segala sesuatu yang dapat digunakan untuk membuat pasangan suami istri melakukan hubungan seksual, seperti dalam hal pakaian. Atmaja dalam Suwantana (2011: 54) juga menyatakan hubungan seksual yang sah dan sakral, dianjurkan agar hubungan yang melampaui badan. Artinya, hubungan seksual memiliki dua tugas pokok, yaitu melanjutkan keturunan yang berkualitas dan mencapai kenikmatan yang magis.

Seks yang magis dalam hal ini dimaksudkan adalah hubungan seksual tidak hanya berupa kenikamatan badan tetapi melampaui batas duniawi. Hubungan seksual yang melampaui badan akan menjadi sebuah sadhana spiritual yang menghantarkan seseorang menuju pencerahan. Adapun beberapa konsep seksualitas yang termuat dalam Lontar Tingkahing Sarasmi, antara lain:

\subsubsection{Konsep Religius Dalam Lontar Tingkahing Sarasmi}

Religius adalah rasa tahu terhadap keberadaan Ida Sang Hyang Widhi Wasa yang membuat semua makhluk hidup terutama manusia selalu mengucap syukur atas karunia dan kesejahteraan yang didapatkan di dunia ini, maka hendaknya patut mengucap syukur kepada Ida Sang Hyang Widhi Wasa. Religius tersebut kecenderungan rohani manusia untuk berhubungan dengan alam dan berupa penghayatan kepada nilai-nilai agama yang tidak hanya ditandai dengan melaksanakan pesembahyangan namun pada keyakinan, pengalaman, dan pe- ngetahuan tentang agama yang dianut.

Keyakinan terhadap Ida Sang Hyang Widhi Wasa dapat membawa umatnya kedalam jalan menuju moksa (moksartham jagadhita ya ca iti Dharma) yang memiliki arti dharma atau agama sebagai inti utama yang digunakan untuk memperoleh moksa (moksartham) serta memperoleh kesejahteraan dalam kehidupan (jagadhita). Moksa juga dapat disebut "mukti" yang berarti memperoleh kebebas lahir batin. Selain itu, bersumber dari agama atau keyakinan bahwa manusia lahir berdasarkan yadnya, sehingga berdasarkan hal tersebut menimbulkan 
persembahan-persembahan suci yang disebut dengan yadnya. Bersumber dari yadnya, maka akan menimbulkan adanya upacara sebagai sarana bhakti kepada Ida Sang Hyang Widhi Wasa. Keyakinan terhadap Ida Sang Hyang Widhi Wasa dapat menyatukan jiwa dan raga manusia. Dalam Lontar Tingkahing Sarasmi, terdapat mengenai konsep religius karena dalam lontar ini membahas bahwa dalam setiap bagian tubuh manusia terdapat lingga/stana atau persemayaman dewa-dewi.

Pada Lontar Tingkahing Sarasmi, terdapat mengenai konsep religius karena dalam lontar ini membahas bahwa dalam setiap bagian tubuh manusia terdapat lingga/stana atau persemayaman dewa- dewi, yaitu: Aji Dewangga Citra, Aji Citra Bhuwana, dan Aji Suksma Jahinang. Aji Dewangga Citra berasal dari kata 'Aji' yang berarti teks suci, sedangkan 'Dewangga' berasal dari kata dewa yang berarti dewa dan angga berarti badan, jadi dewangga dapat berarti badan dewa, dan 'Citra' berarti perwujudan yang cemerlang atau beraneka warna. Maka Aji Dewangga Citra adalah teks suci yang membahas mengenai perwujudan yang cemerlang dari badan dewa. Dimana dijelaskan secara rinci pada setiap bagian tubuh khususnya pada bagian atas sampai bagian tengah tubuh manusia terdapat persemayaman dewa- dewi.

Aji Citra Bhuwana berasal dari kata 'Aji' yang berarti teks suci, 'Citra' yang berarti perwujudan yang cemerlang atau beraneka warna dan 'Bhuwana' yang berarti alam atau bumi. Maka Aji Citra Bhuwana dapat berarti teks suci yang membahas mengenai perwujudan alam yang beraneka warna. Dalam Aji Citra Bhuwana dijelaskan persemayaman dewa-dewi yang beraneka warna dalam tubuh manusia. Ketika seorang wanita sudah mulai mengalami menstruasi maka dapat dikatakan sudah memasuki masa dewasa. Sehingga lebih perlu untuk mawas diri, terutama mengenai masalah keperawanan. Keperawanan dapat diartikan secara sederhana yakni selama wanita tersebut tidak melakukan hubungan seksual. Karena keperawanan hanya dapat dimiliki oleh seorang wanita sekali seumur hidup. Sekali melakukan hubungan seksual layaknya suami istri, maka keperawanan tersebut akan hilang. Namun berbeda dengan yang termuat dalam Lontar Tingkahing Sarasmi, yakni terdapat konsep mengenai Aji Suksma Jahinang. Aji Suksma Jahinang adalah membahas mengenai selalu perawan atau keperawanan yang abadi.

Hal tersebut dapat menunjukkan kepercayaan bahwa dalam tubuh manusia terdapat persemayaman dewa-dewi yang membuat umat Hindu percaya jika Ida Sang Hyang Widhi Wasa ada dalam diri manusia itu sendiri. Hal tersebut juga menjelaskan bahwa hubungan seksual dianggap suci karena melibatkan dewa-dewi yang bersemayam pada bagian-bagian tubuh manusia.

\subsubsection{Konsep Penggunaan Seksualitas Dalam Lontar Tingkahing Sarasmi}

Sebagian kepercayaan populer meyakini bahwa insting seksual tidak dijumpai pada masa kanak-kanak dan baruakan muncul pertama kalinya pada saat pubertas (Freud, 2003: 57). Keyakinan ini akan berdampak pada pendidikan seks bahwa anak-anak belum perlu belajar tentang seks. Pendidikan seks sejak usia dini akan berdampak terhadap kematangan diri anak. Pendidikan seks yang diberikan disesuaikan dengan perkembangan anak. Anak-anak yang belum pubertas, pendidikan seks dan informasi seks yang diberikan berbeda dengan anak usia remaja dan dewasa. Pendidikan seks yang diberikan pada saat anak-anak masih pada tahap pengenalan organ tubuh lawan jenis. Pengenalan terhadap jenis kelamin pada anak usia dini akan membangun imaginasi anak tentang gender dan eksplorasi diri yang lebih kreatif. Pada usia remaja bahaya mengenai dampak seks seperti seks pranikah atau seks bebas, penyakit menular seksual (PMS), HIV/ AIDS, dan yang lainnya penting diketahui. Usia ini merupakan masa transisi dari kanak- kanak menuju dewasa.

Mengenai ajaran tentang teknik persenggamaan, hanya diajarkan kepada pasangan 
suami istri. Jika sudah mengenal pendidikan seks maka setidaknya akan mengetahui bagaimana dan kapan seharusnya seks tersebut digunakan. Pada Lontar Tingkahing Sarasmi terdapat konsep penggunaan seksualitas yang diperuntukkan untuk pasangan suami istri guna tercapainya keharmonisan rumah tangga. Keharmonisan rumah tangga bergantung dari kehidupan seksual dari pasangan suami istri itu sendiri. Sehingga sangat penting mengetahui bagaimana seks tersebut digunakan, seperti sebagai berikut: konsep sanggama berdasarkan waktu, konsep Aji Smaragama, konsep Sastra Aji Pangguli Tiga, dan konsep sanggama berdasarkan posisi.

Pertama terdapat konsep sanggama berdasarkan waktu yakni dijelaskan bahwa waktu pasangan suami istri melakukan hubungan seksual dapat mempengaruhi karakter dari anak yang akan lahir. Pada Lontar Tingkahing Sarasmi dijelaskan bahwa jika melakukan hubungan seksual ketika pagi hari kemudian dianugrahi putra atau putri, dikatakan bagai semut hitam warna kulitnya namun memiliki kepintaran. Jika melakukan hubungan seksual ketika tengah hari maka jika kemudian dianugrahi utra atau putri dikatakan tubuh dari anak tersebut akan berwarna kemerahan, jika berjenis kelamin laki-laki maka rupanya akan tampan, jika berjenis kelamin peremuan makan akan itu akan cantik dan pintar. Dan jika hubungan seksual ketika sore hari maka anak yang dianugrahi kulitnya akan berwana kuning, baik berjenis kelamin laki-laki ataupun perempuan dikatakan akan memiliki wajah yang tampan dan cantik, pintar serta memiliki sifat yang bijaksana.

Konsep Aji Smaragama yaitu membahas mengenai persiapan menurunkan putra. Jika dilihat dari kata yang membentuknya, Aji Smaragama terdiri dari dua kata, yakni Aji yang berarti teks suci dan Smaragama yang berarti bersenggama atau bersetubuh. Jadi Aji Smaragama adalah teks suci yang membahas mengenai bersenggama atau bersetubuh. Dijelaskan pula, jika pasangan suami istri menginginkan dikaruniai anak lakilaki maka persiapannya adalah dengan menutup lubang hidup bagian kiri dengan kapas dan bernafas melalui lubang hidung bagian kanan. Sedangkan jika menginginkan anak perempuan maka persiapan yang dilakukan adalah dengan melakukan sebaliknya yakni menutup lubang hidung bagian kanan dan bernafas menggunakan lubang hidung bagian kiri.

Konsep Sastra Aji Pangguli Tiga yaitu mengenai bagaimana tata cara memperoleh anak laki-laki atau anak perempuan. Pada Lontar Tingkahing Sarasmi menjelaskan bahwa jika suami istri melakukan hubungan seksual pada waktu senja maka akan dianugrahi putra dengan warna kulit agak kehitaman, jika laki-laki maka akan tampan dan pintar. Selanjutnya jika melakukan hubungan seksual pada tengah malam maka akan dianugrahi putra yang kemerahan warna kulitnya, jika laki-laki akan tampan dan bijaksana, dan jika perempuan akan cantik dan pintar. Namun jika melakukan hubungan seksual pada siang hari maka akan dianugrahi putra yang berwarna agak kuning kulitnya, jika laki-laki akan tampan dan memiliki firasat yang tajam, dan begitu pula jika perempuan. Serta jika berkeinginan untuk mengetahui jenis kelamin dari putranya dapat diketahui melalui hembusan nafas ketika melakukan hubungan seksual. Jika hembusan nafas deras disebelah kanan maka lakilaki anaknya, jika hembusan nafas deras disebelah kiri maka perempuan anaknya.

Selanjutnya konsep sanggama berdasarkan posisi yaitu mengenai terdapat lima posisi dalam berhubungan seksual. Sebagai pasangan suami istri, seharusnya dapat berperilaku yang baik dan tidak diperbolehkan untuk memaksa ataupun memiliki nafsu yang tidak terkendali ketika melakukan hubungan seksual atau senggama. Sang suami tidak diperbolehkan untuk mengikuti keinginannya saja atau egois. Ketika melakukan hubungan seksual sepatutnya menggunakan perasaan dari suami dan istri agar hubungan seksual tersebut berjalan 
didasarkan pada rasa cinta dan kasih sayang. Pada Lontar Tingkahing Sarasmi dijelaskan bahwa jika melakukan hubungan seksual dengan posisi ditengah, dikatakan terdapat persemayaman Hyang Saci dengan Dewi Saraswati yang merupakan puncaknya rasa utama atau kenikmatan seksual. Ketika melakukan hubungan seksual dengan menggunakan posisi ditengah maka caranya adalah pertemukan pandangan suami dan pandangan istri, pusar dengan pusar, tangan dengan tangan dan kaki dengan kaki. Selanjutnya jika ingin melakukan hubungan seksual dengan posisi dibawah, yang merupakan persemayaman Dewi Panggegesangan.

Jika ingin melakukan hubungan seksual dengan posisi dibawah maka harus memperhatikan waktu lamanya berhubungan. Pada posisi disebelah kanan, bersemayam bidadari Wilotama. Bila ingin melakukan hubungan seksual dengan posisi di sebelah kanan, maka kaki kanan sang istri harus dilipat. Kemudian pada posisi diatas, bersemayam Hyang Smara Wadhu. Selanjutnya dijelaskan, bila ingin melakukan hubungan seksual dengan posisi diatas maka caranya dengan pertemukan antara gempol pantat sang istri dan gempol pantat sang suami. Dikatakan pula pada posisi disebelah kiri terdapat persemayaman Dewi Supraba. Jika berkeinginan berhubungan seksual dengan posisi disebelah kiri maka caranya dengan kaki kiri sang istri harus dilipat, ditambah letakkan bantal pada bagian punggung sang istri.

Kehidupan seksual merupakan salah satu faktor yang menentukan kebahagiaan bagi suatu pasangan. Kehidupan seksual yang harmonis merupakan kehidupan seksual yang bisa dinikmati oleh pasangan secara bersamasama. Kehidupan seksual disebut tidak harmonis atau tidak membahagiakan apabila salah satu pihak atau keduanya tidak dapat menikmatinya. Bahkan tidak sedikit yang justru tersiksa ketika melakukan aktivitas seksual dan hubungan seksual (Pangkahila, 2005: 108). Pendapat dari Pangkahila tersebut menyatakan bahwa keharmonisan rumah tangga bergantung dari kehidupan seksual dari pasangan suami istri itu sendiri. Sehingga sangat penting mengetahui bagaimana seks tersebut digunakan.

\subsection{Etika Seksualitas Dalam Lontar Tingkahing Sarasmi}

Masyarakat Bali telah memiliki kode etik tersendiri mengenai aktivitas seksual. Kode etik ini telah melembaga ke dalam bentuk perkawinan yang sarat dengtan simbol-simbol, seperti simbol seks, tuntunan-tuntunan hidup atas perubahan status, etika dalam menjalin hubungan dengan pasangan, tujuan yang ingin dicapai dalam perkawinan, dan lain sebagainya. Simbol-simbol ini akan memberikan pelajaran etika kepada kedua pasangan lawan jenis yang ingin mengikatkan diri bersama dalam satu atap.

Pada upacara perkawinan terdapat upacara pekala-kalaan yang tujuannya untuk menyucikan benih kama bang dan kama petak yang telah dipersiapkan untuk segera melahirkan anak yang suputra (Suwantana, 2011: 111). Dalam prosesi upacara perkawinan terdapat rangkaian tikeh dadakan, yaitu merobek tikeh dengan keris yang menyimbolkan bahwa kedua mempelai akan mengakhiri masa lajangnya menuju jenjang kehidupan yang baru. Mempelai wanita akan segera mengakhiri keperawanannya yang disimbolkan dengan tikeh yang ditusuk dengan keris, yakni simbol alat kelamin laki-laki itu sendiri. Nilai etik dari simbol yang dimunculkan dalam upacara pekala-kalaan ini adalah hubungan seksual yang baru boleh dilakukan setelah diadakan upacara perkawinan. Sebelum upacara perkawinan, hubungan seksual tidak boleh dilakukan, bahkan menyentuh pun tidak boleh. Bila seks laki-laki akan dipertemukan dengan seks perempuan maka harus melalui proses upacara perkawinan.

Hubungan antara manusia dengan manusia (pawongan), sangat ditekankan adanya sebuah perilaku yang harmonis. Perilaku yang harmonis ini dalam lingkup yang paling kecil terletak pada 
keluarga khususnya hubungan antara suami dan istri. Keharmonisan hubungan suami istri akan terwujud apabila segala kebutuhannya tercukupi, termasuk di dalamnya adalah seks. Seks yang harmonis akan mewujudkan keluarga yang harmonis. Disini, pokok yang menyebabkan hubungan harmonis adalah adanya komunikasi yang baik. Kesuksesan suatu hubungan banyak dibangun dan ditentukan oleh komunikasi yang merupakan fondasi dalam ikatan suatu hubungan.

Prinsip harmonis adalah prinsip keseimbangan yang tujuan akhirnya adalah pembebasan. Seks yang harmonis menjadi suatu landasan bagi tercapainya pembebasan. Pembebasan yang tercapai memerlukan tata perilaku seks yang menunjang arah tersebut. Etika seksualitas ini menjadi diperlukan ketika menjadi suami istri. Ini berarti bahwa sebelum bersuami istri, hubungan seksual pantang dilakukan. Pantangan ini menjadi etika sesualitas yang berlaku secara umur dalam diri pribadi-pribadi dan yang terpenting adalah etika dalam urusan hubungan suami istri. Kode etik atau etika ini nantinya akan melahirkan kehidupan rumah tangga yang utuh. Hubungan seksual baru bisa dilakukan apabila sudah bersuami istri, namun setelah bersuami istri pun terdapat pantangan-pantangan yang harus dipatuhi. Upacara perkawinan bukanlah sebagai legitimasi untuk melakukan hubungan seksual sebebas-bebasnya.

Pada Lontar Tingkahing Sarasmi membahas etikaseksualitasmengenaidaricaramemperlakukan seorang istri hingga cara memperoleh putra atau anak yang diinginkan. Diantaranya terdapat: (1) etika bersenggama dengan istri, (2) etika memangku istri, (3) etika menginginkan putra suputra, (4) etika menginginkan putra sakti, (5) etika menginginkan putra sidha utama, (6) etika menginginkan putra rupawan, dan (7) etika menginginkan putra panjang. Etika tersebut berupa rapalan mantra-mantra yang diucapkan ketika melakukan hubungan seksual.
Demikian uraian mengenai etika seksualitas yang terdapat dalam Lontar Tingkahing Sarasmi. Secara etika, seksual lebih berorientasi pada nilai kemanusiaan sehingga dibuat etika seksualnya. Berdasarkan ilmu ilmiah atau biologis, memang sulit dicari hubungan diterapkan atau tidaknya etika seksual terhadap karakter anak yang lahir. Namun menurut budaya dan hukum Hindu, hal tersebut sangat berpengaruh. Jika hubungan seksual dilakukan dengan liar atau tanpa kendali akan mempengaruhi karakter dari anak yang dihasilkan. Hal tersebut dapat dilihat pada cerita-cerita Hindu, seperti karakter Rahwana dipengaruhi oleh hubungan seksual yang dilakukan oleh Rsi Wisrawa dengan Dewi Kaikesi, dimana ketika hubungan seksual tersebut dilakukan pada waktu yang tidak tepat dapat menyebabkan anak yang dilahirkan mempunyai karakter yang jahat. Sehingga lahirlah Rahwana dengan kepribadian setengah brahmana dan setengah raksasa.

\subsection{Implikasi Seksualitas Dalam Lontar Tingkahing Sarasmi Terhadap Masyarakat Di Kecamatan Denpasar Timur}

Perilaku konsumtif masyarakat di Kecamatan Denpasar Timur akibat perkembangan zaman dan teknologi terutama dalam hal pariwisata telah membawa dampak pada berubahnya tata nilai hidup masyarakat. Dimana kebiasaan dan gaya hidup masyarakat secara garis besar menuju ke arah kehidupan mewah dan cenderung berlebihan. Perilaku konsumtif juga menyebabkan seseorang terbiasa memiliki pola hidup yang boros sehingga tidak dapat membedakan antara kebutuhan atau sekedar keinginan. Maka hal tersebut akan dapat mendorong terjadinya tindakan tidak terpuji seperti mencuri, menodong, menjadi pemeras, membunuh, melacur, dan lain sebagainya.

Perilaku konsumtif ini dapat terjadi karena ada dua faktor, yaitu faktor internal dan eksternal. Faktor internal adalah faktor dari dalam diri individu, termasuk motivasi, harga diri, observasi, proses belajar, kepribadian, dan konsep diri. 
Sedangkan faktor eksternal adalah faktor di luar individu, termasuk kebudayaan, kelas sosial, kelompok-kelompok sosial dan refrensi serta keluarga.

\section{Lontar Tingkahing Sarasmi merupakan} karya sastra yang didalamnya terkandung nilai bahwa hubungan seksual adalah hal yang suci jika sudah melewati upacara pernikahan. Jika masyarakat sebagian besar untuk memenuhi kebutuhan hidupnya dapat melakukan perilaku yang menyimpang seperti melacur atau pun akibat perkembangan zaman dan teknologi yang membuat terjadinya pergeseran gaya hidup masyarakat yang sudah menganggap lazim seks bebas maka akan sangat bertentangan sekali dengan nilai yang terkandung dalam lontar tersebut. Namun jika dapat dipahami dan dilaksanakan ajaran seksual dalam Lontar Tingkahing Sarasmi akan dapat membantu pasangan suami istri untuk memperoleh seorang anak yang diinginkan. Serta jika masyarakat memahami ajaran tersebut maka tidak akan adanya perilaku menyimpang terutama terkait hubungan seksual, seperti seks bebas, hamil di luar perkawinan, pelecehan seksual dan lain sebagainya yang dapat menghasilkan tabiat anak yang kurang baik. Masyarakat di Kecamatan Denpasar Timur, sangat beragam dan terdiri dari berbagai profesi dalam kesehariannya. Sehingga dalam kehidupan seksual, terutama dalam etika melakukan hubungan seksual banyak memiliki pandangan atau persepsi masingmasing. Sehingga hal ini menyebabkan anak-anak yang terlahirpun tidak semuanya merupakan anak yang diinginkan oleh orang tuanya dan hubungan rumah tangga berjalan kurang harmonis. Adapun implikasi seksualitas dalam Lontar Tingkahing Sarasmi terhadap masyarakat di Kecamatan Denpasar Timur, yakni:

\subsubsection{Implikasi Terhadap Gaya Hidup}

Perkembangan teknologi media massa yang kian cepat, memberikan pengaruh yang besar terhadap lingkungan. Media massa merupakan sarana komunikasi yang menyebarkan informasi dengan cepat kepada masyarakat yang luas dan majemuk. Media massa dapat dikelompokkan menjadi dua, yaitu media cetak dan media elektronik. Media cetak merupakan suatu alat yang digunakan dalam komunikasi untuk membagikan informasi dalam bentuk tulisan dan memiliki kelebihan dapat dibawa kemana-mana serta informasi yang disajikan dapat didokumentasikan.

Perkembangan teknologi media massa yang semakin canggih, baik itu pada media cetak dan elektronik menuntut masyarakat secara tidak langsung harus mampu untuk mengikutinya. Hal tersebut juga memberikan pengaruh besar terhadap gaya hidup masyarakat terutama masyarakat yang tergolong dibawah umur atau remaja. Dimana, remaja direpresentasikan sebagai konsumen fashion, gaya dan konsumtif sebagai anak muda yang selalu mengikuti pula perkembangan teknologi dan mempelajari segala kecanggihan yang dimiliki alat-alat tersebut. Kemudahan dan kecanggihan dari teknologi ini memiliki dampak yang positif untuk kemudahan belajar, namun efek negatif yang ditimbulkan juga tidak kalah besar, seperti kemudahan mengakses situs-situs dan gambar yang tidak selayaknya jika dilihat oleh masyarakat yang belum cukup umur, namun dengan perkembangan teknologi ini hal tersebut menjadi bebas terpublikasikan. Sehingga masyarakat yang tidak mendapat penjelasan dan pendidikan yang memadai tentang hal tersebut maka akan berdampak negatif pada kehidupannya.

Media cetak seperti majalah yang menyajikan gambar-gambarbersifatpornografidan cerita-cerita tentang kisah percintaan yang memperlihatkan keromantisan dari hubungan sebuah pasangan. Majalah tersebut memberikan suatu gambaran sebuah pesan tertentu yang mengakibatkan terjadinya sebuah rangsangan (stimulus) sehingga menimbulkan suatu tanggapan (respon) bagi pembacanya. Respon yang ditimbulkan oleh pembaca dapat berbeda-beda terhadap pesan ataupun informasi yang disajikan tergantung dari kepribadian pembaca. Respon yang ditimbulkan tersebut dapat merubah perilaku masyarakat, baik perubahan yang bersifat positif maupun negatif.

Kemudahan yang disediakan media elektronik salah satunya adalah internet. Internet merupakan jaringan global dunia yang dapat diakses dengan memanfaatkan komputer atau handphone, jaringan besar dan sangat luas menghubungkan setiap komputer dari negara ke negara lainnya di 
seluruh dunia dan menyajikan berbagai macam informasi, mulai dari tulisan, gambar, audio, video, dan lainnya. Internet sudah tidak asing bagi masyarakat, bahkan setiap hari masyarakat berinteraksi memanfaatkan kecanggihan internet. Kemudahan dalam mengakses internet disebabkan karena penggunaan internet tidak hanya dapat diakses melalui komputer melainkan dari handphone sudah dapat dilakukan, bahkan saat ini disetiap sekolah dan fasilitas umum sudah disediakan jaringan wifi untuk dapat mengakses internet secara gratis.

Kecanggihan teknologi tersebut justru tidak dimanfaatkan sebaik- baiknya oleh masyarakat. Apabila internet difungsikan dengan baik dapat membantu segala hal atau masalah yang dihadapi oleh masyarakat, mulai dari mencari bahan pekerjaan, gambar, musik, menyalurkan hobi, menambah relasi, menambah teman, sebagai tempat konseling pada blog khusus yang dimiliki oleh seorang konselor, bahkan sampai pada halhal negatif, seperti cerita dan gambar porno, menonton video porno yang sangat mudah diakses sehingga mempengaruhi kognitif masyarakat yang dapat terpengaruh ke dalam video tersebut

Semakin berkembangnya zaman dan teknologi membuat banyak budaya asing yang masuk dan menjadi trend di masyrakat. Hal ini membuat masyarakat cenderung menganggap seksualitas atau hubungan seksual sudah biasa dilakukan meskipun tanpa melalui upacara perkawinan, seperti halnya seks pranikah atau hamil diluar nikah. Menurut Parsons, perilaku manusia didasari oleh empat komponen/ sistem, yaitu: (a) sistem budaya seperti nilai, norma sosial, keyakinan, kepercayaan, adat istiadat, hukum dan aturan, (b) sistem sosial seperti kerangka tindakan berpola dalam kehidupan sosial manusia, (c) sistem kepribadian seperti tindakan manusia untuk memenuhi hasrat dan motivasi dalam kehidupan, dan (d) sistem organisme yang berfungsi dalam proses adaptasi dengan lingkungan masya

rakat (Sarwono, 2007: 23).

Nilai seks terkandung dalam norma sosial, adat istiadat dan ajaran agama yang hidup dalam masyarakat. Maka gaya hidup yang dipengaruhi dengan mengikuti erkembangan zaman akan menyimpang dari nilai-nilai yang terkandung dalam Lontar Tingkahing Sarasmi yakni etika seksualitas dalam melakukan hubungan seksual.

\subsubsection{Implikasi Terhadap Perilaku Sosial Masyarakat}

Manusia sebagai makhluk sosial berarti manusia sebagai makhluk yang memiliki dimensi kebersamaan dengan orang lain. Teori Psikoanalisa misalnya, menyatakan bahwa manusia memiliki pertimbangan moral sosial (super ego) ketika dihadapkan pada pilihan-pilihan berperilaku. Sedangkan ilmu humaniora menjelaskan realitas sosial sebagai sebuah organisme hidup dalam bentuk teori-teori sosial tentang kehidupan manusia dalam bentuk masyarakat.

Menurut teori psikososial maupun teori perkembangan kognitif menyatakan bahwa perilaku yang ada pada diri seseorang berlandaskan pada pertimbangan-pertimbangan moral kognitif. Selanjutnya, masalah aturan, norma, nilai, etika, akhlak dan estetika adalah hal-hal yang sering didengar dan selalu dihubungkan dengan konsep moral ketika seseorang akan menetapkan suatu keputusan perilakunya. Dalam diri setiap manusia terdapat dua faktor utama yang sangat menentukan kehidupannya, yaitu fisik dan jiwa. Pemahaman terhadap kedua faktor ini memberikan pengaruh yang sangat besar terhadap bagaimana seseorang berperilaku dalam realitas kehidupan. Kedua faktor ini memiliki ruang dan dimensi yang berbeda.

Jika yang pertama adalah sesuatu yang sangat mudah untuk dilihat oleh indra, tampak dalam bentuk perilaku, namun pada faktor yang kedua hanya dapat dirasakan dan menentukan terhadap baik buruknya suatu perilaku. Perilaku manusia adalah suatu fungsi dari interaksi antara individu dengan lingkungannya. Karena pada hakikatnya individu memiliki keunikan masing-masing yang membedakan satu dengan yang lain. Inilah yang disebut manusia sebagai makhluk individu. Seringkali orang menganggap sikap dan perilaku itu sama, padahal dalam berbagai literatur disebutkan bahwa sikap dan perilaku itu berbeda. Para peneliti klasik memang mengutarakan bahwa sikap itu sama dengan perilaku, sebelum adanya 
penelitian terkini yang membedakan antara sikap dan perilaku. Pada umumnya, sikap cenderung memprediksikan perilaku jika kuat dan konsisten, berdasarkan pengalaman langsung seseorang dan secara spesifik berhubungan dengan perilaku yang diprediksikan

Perilaku sosial merupakan tindakan-tindakan yang berkaitan dengan segala perbuatanyang secara langsung berhubungan atau dihubungkan dengan nilai-nilai sosial yang ada dalam masyarakat. Atau dapat dikatakan bahwa perilaku sosial merupakan tindakan-tindakan yang berkaitan dengan segala perbuatan yang secara langsung berhubungan atau dihubungkan dengan nilai-nilai sosial yang ada dalam masyarakat. Terdapat empat faktor utama yang dapat membentuk perilaku sosial, yaitu: (1) Perilaku dan karakteristik orang lain, (2) Proses Kognitif, (3) Faktor Lingkungan, dan (4) Latar Budaya. Keempat faktor tersebut sangat mempengaruhi perilaku seseorang untuk menerapkan atau tidaknya etika seksualitas dalam Lontar Tingkahing Sarasmi.

Implikasi Terhadap Masyarakat Yang Menerapkan Etika Seksualitas Dalam Lontar Tingkahing Sarasmi

Pada zaman yang semakin berkembang ini membuatpemikiranmanusiajugaikutberkembang. Namun karena kurangnya kesiapan mental untuk menerima perubahan dan perkembangan tersebut, tidak jarang justru mengahasilkan perilaku yang menyimpang atau tidak baik. Banyak masyarakat yang cenderung mengikuti perkembangan zaman tanpa berpikir panjang apa dampak yang akan dihasilkan nantinya, tetapi ada pula masyarakat yang ditengah perkembangan zaman ini masih memegang nilai atau norma-norma yang sudah diwariskan oleh leluhurnya. Salah satunya adalah mengenai etika seksualitas dalam berhubungan suami istri.

Hindu menganggap seks tersebut suci jika dilakukan setelah melalui upacara pernikahan sehingga yang dapat melakukan hubungan seksual tersebut hanya pasangan suami istri yang sah secara agama dan hukum. Etika seksualitas tersebut terkandung dalam Lontar Tingkahing Sarasmi. Dimana dalam etika seksual ini menjelaskan mengenai etika melakukan hubungan seksual dengan istri sampai etika memperoleh putra atau anak yang diinginkan. Etika seksualitas dalam Lontar Tingkahing Sarasmi dibagi menjadi 7 macam, yaitu: (1) etika bersenggama dengan istri, (2) etika memangku istri, (3) etika menginginkan putra suputra, (4) etika menginginkan putra sakti, (5) etika menginginkan putra sidha utama, (6) etika menginginkan putra rupawan, dan (7) etika menginginkan putra panjang umur.

Jika etika seksualitas tersebut dapat diterapkan oleh masyarakat maka akan dapat membuat hubungan suami istri menjadi harmonis. Dimana etika bersenggama dengan istri dan etika memangku istri yang cenderung lebih dikenal dengan istilah foreplay jika diterapkan ketika melakukan hubungan seksual maka akan membuat pasangan suami istri terpenuhi keinginan seksualnya. Masyarakat yang menerapkan etika seksualitas dalam Lontar Tingkahing Sarasmi cenderung memperoleh anak yang diinginkan, yaitu anak yang suputra karena memiliki anak yang suputra merupakan keinginan sebagian besar pasangan suami istri dan terwujudnya keharmonisan rumah tangga karena dalam Lontar Tingkahing Sarasmi juga membahas mengenai tata cara memperlakukan seorang istri, seperti etika bersenggama dengan istri dan etika memangku sang istri.

Selain mengenai etika eksualitas bersenggama dengan istri, terdapat pula etika seksualitas menginginkan putra suputra. Untuk mewujudkan keinginan memiliki putra yang suputra, orang tua atau pasangan suami istri sudah harus mengikuti aturan tata cara atau etika berhubungan seksual, ditambah memberikan pendidikan dan lingkungan keluarga yang baik untuk tumbuh kembang anak sejak dini.

Sukerta (2018: 160) mengatakan hubungan seksual suami istri haruslah dipilih hari baiknya, ini bertujuan untuk menurunkan putra yang suputra mahotama, penurut, pintar, berbakti kepada orang tua, murah rezeki dan berwibawa, bila tidak maka keturunan yang akan terlahir akan menyebabkan kesusahan bagi keluarga dan lingkungannya. Maka dari pernyataan tersebut, sudah jelas jika ingin mempunyai putra yang suputra haruslah dipersiapkan dimulai dari ketika melakukan hubungan seksual. 
Berdasarkan Hindu, setiap wewaran dari Ekawara sampai dengan Dasa Wara itu dikuasai oleh Dewanya yang mempunyai sifat yang berbeda pula. Begitu juga purnama dan tilem merupakan hari-hari Yoganya Dewa. Termasuk implikasi penanggal-panglong terhadap kromosom dan metabolisme sel sperma dan sel telur saat pembuahan. Sedangkan peran keluarga merupakan aspek sosiologis yang sangat ditentukam oleh kualitas sumber daya manusia dalam keluarga, baik dimensi kualitas kecerdasan intelektual, emosional maupun spiritual anggota keluarga bersangkutan terhadap pembentukan anak suputra disamping implikasi lingkungan sosialnya.

Terwujudnya atau diperolehnya putra suputra, selain dengan menerapkan etika seksualitasnya namun tidak terlepas pula dari peran seluruh anggota keluarga. Keluarga berasal dari bahasa Sansekerta yakni dari kata kula yang artinya abadi atau hamba dan warga yang artinya jalinan atau ikatan pengabdian. Terbentuk dari kata kula dan warga menjadi kulawarga yang berarti anggota atau kelompok kerabat. Jadi keluarga dapat diartikan secara bebas sebagai lingkungan dimana beberapa orang masih memiliki hubungan darah. Sedangkan kata suputra (Sukerta, 2018: 197) adalah anak yang memiliki kesadaran akan Tuhan dan berjalan dalam pondasi dharma, dan sejahtera berarti terpenuhi segala kebutuhan lahir dan batin, bhoga, upabhoga, paribhoga, yaitu sandang, pangan, dan papan serta jalinan kasih yang sejati.

\subsubsection{Implikasi Bagi Masyarakat Yang Tidak Menerapkan Etika Seksualitas Dalam Lontar Tingkahing Sarasmi}

Seks adalah sesuatu yang sakral sehingga tidak boleh dilakukan sembarangan. Di dalam kitab Ayur Weda tertera aturan tentang hubungan seks yang disebut Mithuna. Tidak hanya mengatur soal waktu, tetapi juga pantangan- pantangan dalam berhubungan. Pada ajaran etika agama Hindu dan beberapa larangan untuk melakukan hubungan seksual seperti, hubungan suami istri sebelum menikah, pada hari-hari suci Hindu, tempat-tempat suci, tempat-tempat umum, di dapur, di sungai yang disucikan, di kandang sapi, dan di luar kelayakan. Hubungan ini disebut hubungan seksual yang adharma. Jika hasil hubungan ini terjadi pembuahan maka makhluk yang lahir adalah makhluk yang disebut kumiligi. Makhluk ini adalah makhluk yang tingkatannya lebih rendah dari pada manusia, yang dalam proses penyempurnaan dirinya sangat menginginkan kesempatan menjadi manusia, namun Tuhan mengizinkan untuk menjelma menjadi manusia melalui orang- orang yang melakukan hubungan seksual yang adharma, yang mana waktu dan tempat yang tidak benar. Demikian halnya dengan kehamilan di luar perkawinan, melakukan hubungan seksual tanpa menghiraukan etika seksualnya merupakan kesempatan utama bagi penjelmaan Panca Kumiligi tersebut. Swastika (2010: 177) menguraikan kelima mkhluk panca kumiligi, yaitu:

1. I Nguntang disimbolkan dengan perwujudan tangan manusia.

2. I Nganting disimbolkan dengan kaki.

3. I Bongol disimbolkan dengan tubuh tanpa kepala.

4. I Tundik disimbolkan wujud Bhuta dengan posisi tangan menunjuk.

5. I Ngulaleng disimbolkan wujud sebagai bhuta sangsang atau terbalik.

Jika I Nguntang dan I Nganting yang menjelma, dicirikan dengan anak yang apabila marah justru menyiksa diri sendiri, jika I Bongol yang menjelma maka anak yang lahir akan tidak pernah menghiraukan larangan orang tua dan nasehat yang diberikan dianggap angin lalu saja. Jika I Tundik menjelma maka si anak akan sering meminta sesuatu, uang atau benda pada orang yang bertamu ke rumahnya, ciri parah dari penjelmaan I Tundik, si anak memiliki sifat suka mencuri sedangkan jika I Ngulaleng yang menjelma, anak akan seing berlari ke luar rumah atau ke jalan dan jika sudah agak besar maka anak akan lupa segalanya kalau sudah bermain, lupa makan, dan lupa pulang.

Setiap jenis kehidupan ingin bereinkarnasi menjadi manusia, jika tumbuhan ingin menjelma menjadi hewan, sebaliknya hewan-hewan ingin menjelma menjadi manusia. Hanya cukup disayangkan setelah menjelma sebagai manusia, banyak manusia yang tidak mempertahankan kemanusiaannya yang pada akhirnya kembali 
menjadi binatang. Seperti orang yang melakukan tindakan brunaha atau mengugurkan bayi dalam kandungannya karena semata- mata untuk mempertimbangkan kebaikan dirinya sendiri berakibat karena karma yang sangat buruk ia akan lahir di kandang srigala

Demikian akibat jika melakukan hubungan seksual tanpa memperhatikan etika seksualnya sehingga dapat menghasilkan anak yang tidak diinginkan terutama mengenai karakter anak. Dalam Lontar Tingkahing Sarasmi sudah dijelaskan dengan baik dan terperinci bagaiman etika seksual hubungan suami istri sehingga dapat memperoleh anak yang diinginkan. Selain itu, anak yang lahir dari hubungan seksual yang tidak beretika atau terkendali cenderung menjadi anak yang kuputra. Kuputra merupakan anak yang durhaka kepada orang tua, dimana anak yang jahat dan melakukan perbuatan dosa yang dapat menjerumuskan dirinya sendiri dan masyarakat sekitarnya ke dalam penderitaan.

\section{PENUTUP}

Lontar Tingkahing Sarasmi merupakan salah satu karya sastra berupa lontar yang mengandung konsep seksualitasyaknikonsep religius dankonsep penggunaan seksualitas. Dalam konsep tersebut banyak dibahas mengenai persemayaman dewadewi dibagian tubuh manusia. Etika seksualitas yang terdapat dalam Lontar Tingkahing Sarasmi yakni berupa tata cara memperlakukan seorang istri hingga cara memperoleh putra atau anak yang diinginkan. Adapun implikasi seksualitas dalam Lontar Tingkahing Sarasmi terhadap masyarakat di Kecamatan Denpasar Timur, yakni implikasi terhadap gaya hidup, implikasi terhadap perilaku sosial masyarakat, implikasi terhadap masyarakat yang menerapkan etika seksualitas dalam Lontar Tingkahing Sarasmi, dan implikasi terhadap masyarakat yang tidak menerapkan etika seksualitas dalam Lontar Tingkahing Sarasmi.

\section{DAFTAR PUSTAKA}

Djaya dan Asmara. 2004. Asmaragama Wanita Jawa, Spiritualitas dan Pesona

Seksualitas Dalam Kearifan Tradisional. Yogyakarta: Yogyakarta.
Freud, Sigmud. 2003. Pengantar Umum Psikoanalisis. Yogyakarta: Pustaka Pelajar.

Pangkahila, W. 2005. Disfungsi Seksual Pria. Pusat Studi Andrologi dan Seksologi Fakultas Kedokteran Universitas Udayana.

Sarwono, S.W. 2007. Psikologi Remaja. Jakarta: PT. Rajawali Press.

Suarka, I Nyoman. 2012. Telaah Sastra Kakawin. Denpasar: Pustaka Larasan.

Sukayasa, I Wayan. 2007. Teori Rasa: Memahami Taksu, Ekspresidan M e to de nya. Denpasar: Widya Dharma.

Sukerta, I Ketut. 2018. Teo- Astrologi Hindu Dalam Konsep Biologi Reproduksi Melahirkan Anak Suputra Di Kota Denpasar. Desertasi (tidak diterbitkan). Insititut Hindu Dharma Negeri Denpasar.

Suwastika, Pasek I Ketut. 2010. Grahasta Asrama. Surabaya: Paramita

Suwantana, I Gede. 2011. Seks Sebagai Pendakian Spriritual. Denpasar: Pustaka Bali Post.

Tim Penyusun. 2008. Kamus Besar Bahasa Indonesia Pusat Bahasa Edisi Ke empat. Jakarta: Gramedia. 